Tinjauan Pustaka

\title{
Dampak Klinis Thyroid-Stimulating Hormone
}

\author{
Eva Decroli, Alexander Kam
}

\begin{abstract}
Abstrak
Thyroid-Stimulating Hormone (TSH), yang disebut juga dengan tirotropin, adalah glikoprotein yang disekresikan oleh bagian anterior dari kelenjar hipofisis. Sintesis dan sekresi dari TSH diatur oleh faktor dari hipotalamus yang didominasi oleh thyrotropin-releasing hormone (TRH) dan faktor perifer yang didominasi oleh kadar hormon tiroid. Setelah disintesis, TSH disekresikan, lalu akan berikatan dengan reseptor yang disebut Thyroid-Stimulating Hormone Receptor (TSHR). Ikatan TSH-TSHR akan memberikan dampak klinis terhadap jaringan dan organ tempat terjadinya ikatan tersebut. Ikatan tersebut bisa terjadi pada kelenjar tiroid dan jaringan ekstratiroid. Jaringan yang sudah dikenal mengekspresikan TSHR adalah jaringan adiposa, hipotalamus, hipofisis anterior, tulang, hati dan sistem imun.
\end{abstract}

Kata kunci: thyroid-stimulating hormone, thyroid-stimulating hormone receptor

\begin{abstract}
Thyroid-stimulating hormone (TSH), also known as thyrotropin, is a glycoprotein secreted by the anterior part of the pituitary gland. TSH synthesis and secretion are mainly regulated by thyrotropin-releasing hormone (TRH) at the pituitary level and thyroid hormone at the peripheral level. TSH will attach to its receptor, thyroid-stimulating hormone receptor (TSHR). TSH-TSHR compound mediates its effect on thyroid gland and extrathyroid tissues. Tissues known to express TSHR are adipose tissue, hypothalamus, anterior part of the pituitary gland, bone, liver and immune system.
\end{abstract}

Keywords: thyroid-stimulating hormone, thyroid-stimulating hormone receptor

\author{
Affiliasi penulis: Bagian Penyakit Dalam Fakultas Kedokteran \\ Universitas Andalas Padang/ RSUP Dr. M. Djamil Padang. \\ Korespondensi: Eva Decroli, Email: eva.decroli@yahoo.com, \\ pibipd@yahoo.com, Telp: (0751) 37771
}

\section{PENDAHULUAN}

Thyroid-stimulating hormone (TSH), yang disebut juga dengan tirotropin, adalah glikoprotein yang disekresikan oleh bagian anterior dari kelenjar hipofisis. Thyroid-stimulating hormone selama ini belum banyak dibicarakan walaupun TSH ikut berperan dalam aksis hipotalamus-hipofisis-tiroid. TSH memainkan peran fisiologis yang penting pada pengaturan aksis hipotalamus-hipofisis-tiroid dengan mengatur pelepasan hormon tiroid dari kelenjar tiroid. ${ }^{1,2,3}$

Sintesis dan sekresi dari TSH diatur oleh faktor dari hipotalamus yang didominasi oleh thyrotropinreleasing hormone (TRH) dan faktor perifer yang didominasi oleh kadar hormon tiroid. Tahap sintesis TSH terdiri dari transkripsi, glikosilasi, dan kombinasi dua subunit penyusun TSH yang dibentuk secara independen. Setelah disintesis, TSH disekresikan dan akan berikatan dengan reseptornya, yang disebut dengan thyroid-stimulating hormone receptor (TSHR). Kadar normal TSH dalam darah pada dewasa adalah 2 - $10 \mathrm{mU} / \mathrm{L}$ dan pada neonatus adalah $3-18$ $\mathrm{mU} / \mathrm{L}^{4,5}$

Thyroid-stimulating hormone receptor merupakan G-protein-coupled receptor (GPCR) dan memiliki struktur yang sama pada kelompok reseptor serpentin, yaitu segmen seven membrane spanning, tiga lengkungan ekstraseluler, tiga lengkungan intraseluler, dan sebuah ektodomain terminal amino dan sebuah terminal karboksi intraseluler. Lengkungan intraseluler dari reseptor ini berikatan dengan 3 subunit (trimetrik) protein $G$, yaitu subunit $\alpha, \beta$ dan $\mathrm{y}$. 
Ikatan hormon dengan TSHR akan menghasilkan second messanger yang akan memberikan dampak terhadap sel tempat ikatan tersebut terjadi. Selain TSH, yang dapat mengaktivasi TSHR adalah thyroid stimulating antibodies (TSAb) dan hormon glikoprotein yang baru teridentifikasi, yang dinamakan tirostimulin. Tirostimulin diproduksi pada beberapa jaringan dan bisa mengaktivasi TSHR, dan ini mengemukakan mekanisme regulasi parakrin pada jaringan tersebut. ${ }^{6,7}$

Ikatan TSH-TSHR akan memberikan dampak klinis terhadap jaringan dan organ tempat terjadinya ikatan tersebut. Ikatan tesebut bisa terjadi pada kelenjar tiroid dan jaringan ekstratiroid. Pada kelenjar tiroid, TSHR menyebabkan tirosit mengenali dan merespon TSH yang disekresikan oleh sel tirotropik pada hipofisis. Hal ini mengatur proliferasi tirosit, produksi dan sekresi hormon tiroid. Gangguan transduksi sinyal dari TSH menyebabkan kelainan tiroid, seperti gondok, hipotiroid, dan hipertiroid, yang memiliki manifestasi klinis yang kompleks. Saat ini, ekspresi TSHR fungsional juga ditemukan di luar kelenjar tiroid, dan sampai saat sekarang menjadi hal yang menarik untuk diteliti lebih lanjut peran yang dimiliki oleh TSHR pada jaringan ekstratiroid ini. Jaringan yang sudah dikenal mengekspresikan TSHR adalah jaringan adiposa, hipotalamus, hipofisis anterior, tulang, hati, dan sistem imun. ${ }^{4,6,8,9}$

\section{THYROID-STIMULATING HORMONE}

Thyroid-stimulating hormone (TSH) merupakan sebuah glikoprotein dengan massa molekul 28 - 30 kiloDalton $(\mathrm{kDa})$. Hormon ini merupakan anggota dari kelompok hormon glikoprotein selain folliclestimulating hormone (FSH), luteinizing hormone (LH), dan human chorionic gonadothropine (hCG). Thyroidstimulating hormone disintesis dan disekresikan oleh sel tirotropik kelenjar hipofisis anterior. Sel tirotropik menyusun sekitar $5 \%$ dari sel hipofisis anterior dan terletak di area anteromedial kelenjar. Sel ini lebih kecil daripada tipe sel lain dan berbentuk ireguler dengan nukleus yang tipis dan granul sekretori yang relatif kecil $(120-150 \mu \mathrm{m}){ }^{4,10,11}$

Thyroid-stimulating hormone terdiri dari 2 rantai yang berhubungan secara nonkovalen, yaitu subunit $\alpha$ dan $\beta$ dengan ikatan sulfida sentral. Subunit $\alpha$ adalah subunit yang persis sama dan dimiliki oleh TSH, LH, $\mathrm{FSH}$, dan hCG, sementara subunit $\beta$ merupakan subunit yang unik dan memberikan aksi yang spesifik pada hormon yang disusunnya. Sarapura et al (2011) menyatakan bahwa subunit $\alpha$ ini berperan dalam menerangkan kejadian pubertas prekoks yang bersamaan dengan hipotiroid primer yang berat. Kejadian tersebut mengarahkan bahwa kadar tinggi TSH bisa mengaktivasi reseptor gonadotropin. Interaksi ini sudah ditemukan dengan menggunakan TSH manusia rekombinan, yang ditemukan bisa mengaktivasi $\mathrm{FSH}^{4,11}$

Sintesis TSH dikendalikan oleh sinyal yang dikoordinasikan dari sistem saraf pusat dan umpan balik dari sirkulasi perifer. Input positif yang paling penting untuk sintesis $\mathrm{TSH}$ adalah $\mathrm{TRH}$, dan pengatur negatif yang paling kuat adalah kadar hormon tiroid di sirkulasi. Namun, tambahan faktor hipotalamus dan hormon yang bersirkulasi juga memiliki efek pengaturan yang penting. Kebanyakan faktor ini merupakan efek independen terhadap sintesis 2 subunit dari $\mathrm{TSH}^{4,12,13}$

TSH yang telah disintesis akan disekresikan melalui hasil interaksi yang kompleks antara sentral (hipotalamus) dan hormon perifer. TRH secara langsung mengatur sekresi TSH in vivo dan in vitro dan TRH menentukan set point untuk kontrol umpan balik dari hormon tiroid. Sementara itu, somatostatin (SS) menghambat sekresi TSH dan yang dirangsang oleh TRH secara in vivo dan in vitro. Sekresi TSH kemungkinan diatur melalui sistem kontrol dari stimulasi TRH dan inhibisi SS dari hipotalamus. ${ }^{4,14}$

\section{DAMPAK KLINIS THYROID-STIMULATING HORMONE}

\section{Dampak klinis TSH pada kelenjar tiroid}

Aksi TSH pada reseptor menghasilkan aktivasi pada jalur adenylyl cyclase dan jalur phosphatidylinositol yang menyebabkan aktivasi beberapa protein, termasuk JAK/STAT, mTOR/S6K1 dan protein yang berkaitan dengan siklus sel. Protein yang difosforilasi oleh jalur protein kinase $\mathrm{C}$ tampak berbeda dengan protein yang difosforilasi oleh jalur protein kinase A. Fosfoprotein fosfatase diaktivasi dan menyebabkan defosforilasi set protein yang lain. Efek 
TSH pada kelenjar tiroid termasuk perubahan dalam pertumbuhan kelenjar tiroid, morfologi sel, metabolisme iodin dan sintesis hormon tiroid. ${ }^{2,4,15}$

\section{a. Perkembangan dan pertumbuhan kelenjar tiroid}

Perkembangan embriologik kelenjar tiroid tampaknya tidak bergantung pada $\mathrm{TSH}$, seperti yang tampak pada penelitian yang menggunakan tikus yang mengalami defisiensi TSH dan reseptor TSH yang menunjukkan tidak ada perbedaan dalam ukuran, struktur folikuler, ekspresi faktor transkripsi yang spesifik tiroid dan produksi tiroglobulin. Ekspresi tiroperoksidase dan simporter natrium/iodin dan pemeliharaan arsitektur kelenjar tiroid setelah kelahiran tampak sangat memburuk pada tikus tersebut. Pada kelenjar tiroid dewasa, TSH merupakan pengatur utama pertumbuhan kelenjar tiroid. Setelah rangsangan jangka panjang TSH, kelenjar tiroid membesar akibat hiperplasia dan hipertrofi. TSH memiliki efek proliferasi yang cepat. Hal ini meningkatkan sintesis DNA melalui jalur adenylyl cyclase, terutama melalui jalur protein kinase A. TSH juga mengatur pertumbuhan melalui jalur cAMP-independent, seperti jalur mTOR/S6K1, dan interaksi dengan faktor pertumbuhan epidermal growth factor (EGF) dan insulin-like growth factor-I (IGF-I). TSH meningkatkan transkripsi gen pada sel tiroid tikus. TSH juga menghambat apoptosis, yang kemungkinan dengan mengatur p53 dan bcl-2, seperti yang tampak pada gonadotropin. ${ }^{4,16}$

\section{b. Morfologi sel tiroid}

TSH menyebabkan perubahan dramatis pada morfologi tiroid. Respon awal TSH adalah inkorporasi vesikel eksositotik ke dalam membran sel pada apical pole sel folikuler yang diikuti dengan cepat oleh pembentukan proyeksi sitoplasmatik dan mikrovili. Jumlah proyeksi sitoplasmatik berhubungan dengan kadar TSH. Setelah rangsangan, sel folikuler menjadi kolumner dan diisi oleh droplet koloid. Koloid luminal kemudian menjadi berkurang, yang menyebabkan folikel menjadi kolaps. Sistem sitoskeletal, termasuk miosin, aktin, tropomiosin, kalmodulin, profilin, dan tubulin, berperan dalam proses ini. ${ }^{4}$

\section{c. Metabolisme iodin}

Thyroid-stimulating hormone penting pada simporter natrium/iodin dan ekspresi peroksidase tiroid selama embriogenesis dan kelahiran. Thyroidstimulating hormone mengatur aktivasi posttranskripsi simporter natrium/iodin melalui jalur adenylyl cyclase. Transkripsi peroksidase tiroid dan stabilitas mRNA meningkat oleh TSH juga melalui jalur adenylyl cyclase. Pembentukan peroksidase dan organifikasi iodin tampaknya dimediasi oleh jalur phosphatidylinositol yang independen terhadap protein kinase $C^{2,4}$

\section{d. Sintesis hormon tiroid}

Aksi TSH terakhir adalah produksi hormon tiroid oleh kelenjar tiroid. Proses ini dimulai dengan transkripsi gen tiroglobulin. Jumlah transkripsi dan stabilitas mRNA ditingkatkan oleh TSH. Thyroidstimulating hormone merangsang pengambilan iodin dan organifikasi. Thyroid-stimulating hormone kemudian berperan dalam penyimpanan tiroglobulin yang sudah diiodinisasi di dalam koloid luminal dan menstimulasi hidrolisis yang menyebabkan pelepasan gugus asam amino, termasuk $\mathrm{T}_{3}$ dan $\mathrm{T}_{4}{ }^{4}$

\section{Dampak klinis TSH pada jaringan ekstratiroid}

\section{a. Dampak klinis TSH pada jaringan adiposa}

Pada masa sebelumnya tidak diketahui bahwa adiposit mengekspresikan TSHR. Penelitian pemenang Nobel tahun 1960an yang meneliti protein $\mathrm{G}$ oleh Rodbell juga meneliti lipolisis adiposit dengan menggunakan beberapa ligand termasuk katekolamin dan TSH. Penelitian ini lalu sempat terlupakan hingga pertengahan tahun 1990an dilakukan penelitian yang meng-klon adiposit tikus rodent pada tahun $1995 .^{8}$

Pelepasan asam lemak dari perlipin-coated droplet lemak di dalam adiposit mengikutsertakan aktivasi adipose triglyceride lipase (ATGL) menjadi triagliserol menjadi diagliserol, yang diikuti oleh konversi diagliserol menjadi monogliserol oleh hormone-sensitive lipase (HSL). Langkah terakhir untuk bergabung dengan asam lemak yang lain adalah melalui monoacylglycerol lipase. Fosforilasi perilipin dan HSL penting untuk efektivitas lipolisis. ${ }^{8}$ 
Pada adiposit yang matang, TSH mengatur lipolisis dari trigliserida. TSH merangsang lipolisis pada adiposit, dengan jaringan neonatal memiliki sensitivitas yang lebih tinggi. Hal ini mendukung gagasan mengenai peningkatan TSH pada neonatus bisa memicu lipolisis untuk memenuhi kebutuhan nutrisi saat itu. Pada penelitian dengan sampel hipotiroid subklinis ditemukan peningkatan kadar basal dari non-esterified fatty acid (NEFA) dan gliserol. ${ }^{17,18}$

TSH memiliki efek lipolitik yang penting, Nannipieri et al (2009) menyatakan bahwa efek ini menurun seiring bertambahnya usia. Jiang et al (2015) juga menyatakan bahwa TSH memiliki efek lipolitik yang signifikan pada neonatus, dan pada anak dan dewasa, efek tersebut menurun secara bertahap. Williams (2011) menyatakan bahwa efek lipolitik pada neonatus, terutama pada brown adipose tissue, berperan dalam proteksi terhadap hipotermia. Hal tersebut menjelaskan efek termogenesis yang dimiliki oleh TSH pada neonatus. Efek tersebut pada anak dan dewasa muncul jika kadar TSH dalam darah tidak fisiologis. ${ }^{9,17,18}$

Ma et al (2015) menyatakan bahwa efek TSH terhadap adiposa adalah meningkatkan jumlah adiposit dan merangsang hipertrofi adiposit. Jumlah sel adiposit ditingkatkan dengan mempercepat diferensiasi preadiposit menjadi adiposit. Hal ini terjadi pada usia anak hingga remaja. Hipertrofi adiposit terjadi akibat peningkatan sintesis trigliserida yang dirangsang oleh TSH melalui peningkatan ekspresi glycerol-3-phosphate acyltransferase (GPAT3) via jalur sinyal AMPK/PPARy. GPAT3 adalah enzim di adiposit yang berperan penting dalam adipogenesis. Sintesis trigliserida ini akan menyebabkan terjadinya akumulasi trigliserida dan obesitas. Adiposa yang mengalami hipertrofi akan menyebabkan inflamasi dan menganggu metabolisme glukolipid, sehingga bisa menyebabkan resistensi insulin. Williams (2011) menyatakan bahwa adiposit yang bertambah besar disebabkan karena berkurangnya ekspresi TSHR pada adiposa. Hal ini ditunjukkan pada tikus dengan delesi adipocyte-specific TSHR tidak dapat mengaktivasi lipolisis sebagai respon terhadap TSH sehingga menyebabkan hipertrofi adiposit. ${ }^{9,19}$
Obesitas yang timbul akibat efek TSH akan menimbulkan kelainan metabolik. Mukherjee et al (2013) menyatakan bahwa obesitas akan menghasilkan sitokin proinflamasi yang selanjutnya akan menimbulkan beberapa kelainan. Proinflamasi menimbulkan sindroma metabolik, peningkatan risiko kelainan kardiovaskuler, dan gangguan koagulasi. Walter et al (2012) bahkan menambahkan bahwa stres metabolik yang timbul akibat peningkatan TSH dapat meningkatkan kadar kortisol dalam darah. Ruhla et al (2009) menyatakan bahwa terdapat korelasi antara TSH dengan sindroma metabolik. Chen et al (2013) menyatakan bahwa peningkatan TSH berhubungan dengan perburukan klinis pada pasien dengan gagal jantung. Namun, Debeij et al (2010) menyatakan bahwa sistem koagulasi dipengaruhi oleh hormon tiroid, tidak oleh $\mathrm{TSH}^{20,21,22,23,24}$

Lemak pada orbital berbeda dengan jaringan adiposa yang lain. Lemak tersebut ditemukan mirip dengan brown adipose tissue (BAT). Terdapat beberapa laporan kasus pada anak dengan mutasi TSHR yang lahir dengan proptosis. Walaupun kontroversial, hal ini kemungkinan disebabkan oleh peningkatan adipogenesis orbita yang timbul karena mutasi reseptor. Proses ini sama dengan fenomena yang ditemukan pada pasien dengan oftalmopati Graves. Menurut Raychaudhuri et al (2013) oftalmopati Graves terjadi karena efek dari sitokin seperti interleukin-6 (IL-6) yang dihasilkan dari sel adiposa di bawah pengaruh TSH. Smith (2015) menyatakan bahwa oftalmopati Graves terjadi karena adanya akumulasi hyaluronan yang berhubungan dengan adipogenesis. Hyaluronan disintesis oleh fibroblas CD34+ di orbitasetelah diaktivasi oleh TSH dan beberapa sitokin., ${ }^{6,25,26}$

\section{b. Dampak klinis TSH pada sistem imun}

Penelitian sedang dilakukan untuk menemukan ekspresi dan signaling TSHR di sumsum tulang, timus, darah perifer dan sel imun, limfosit $T$ dan sel dendritik. Sitokin yang meningkat pada pasien dengan peningkatan kadar TSH adalah IL-6, C-reactive protein (CRP), dan monocyte chemoattractant protein-1 (MCP-1). IL-6 diperkirakan menjadi salah satu sitokin 
yang berperan dalam terjadinya thyroid-associated ophtalmopathy (TAO). IL-6 sebelumnya sudah dikenal sebagai faktor diferensiasi sel B yang mendukung sintesis imunoglobulin. Beberapa faktor mengatur produksinya, baik melalui mekanisme transkripsional maupun post-transkripsional. TSH meningkatkan produksi IL-6 pada epitel tiroid dan sel non tiroid, seperti preadiposit 3T3-L1. Sorisky dan Gagnon (2014) menyatakan bahwa pelepasan IL-6 yang dirangsang oleh TSH pada adiposit tergantung pada jalur IKKß/NFkB dan tidak dihambat oleh PKA inhibitor H89. ${ }^{8,25}$

Interleukin-6 (IL-6), seperti sitokin pleiotropik lainnya, diproduksi sebagai respon terhadap rangsangan yang multipel. Interleukin-6 mendukung fungsi sel $B$ dengan mendorong sintesis imunoglobulin dan promosi diferensiasi sel plasma. IL-6 juga mengatur metabolisme lemak dan terlibat dalam proses inflamasi seperti yang terjadi pada TAO. Kadar IL-6 meningkat pada individu dengan penyakit Graves dan kadarnya tinggi pada individu dengan TAO. Kadarnya pada mata TAO berkorelasi lurus dengan ekspansi jaringan. Penelitian terakhir menunjukkan bahwa jalur signaling tanpa cAMP yang terlibat dalam regulasi TSH terhadap IL-6 dalam sel memainkan peran sentral dalam oftalmopati Graves. Terdapat kemungkinan bahwa komponen keterlibatan TSHR pada patogenesis TAO terpisah dari perannya merangsang pembentukan cAMP. Namun, molekul TSHR ini belum diketahui apakah sama secara struktur dan fungsional dengan TSHR pada tiroid. Begitu juga dengan thyroid-stimulating immunoglobulin (TSI) yang belum bisa dibedakan dengan antibodi yang aktif pada fibrosit dalam konteks fungsinya di sirkulasi atau di dalam orbita. Tidak adanya pembentukan cAMP pada fibrosit menunjukkan bahwa sel ini ideal untuk meneliti jalur alternatif yang melibatkan signaling $\mathrm{TSH}^{8,25}$

Pada darah perifer, TSHR diekspresikan pada eritrosit yang bisa mempengaruhi aktivitas $\mathrm{Na} / \mathrm{K}$ ATPase, dan pada limfosit yang efeknya belum jelas. Pada epitel intestinal, reseptor TSHR diekspresikan pada limfosit intraepitelial dan produksi lokal TSH oleh sel epitelial intestinal mengatur rekrutmen, perkembangan, dan fungsi imunoregulasi dari subset spesifik limfosit jaringan intraepitelial. Penelitian lebih lanjut yang menggunakan imunopresipitasi dan teknik flow cytometry menemukan kadar ekspresi TSHR yang tinggi pada fraksi sel dendritik dewasa (CD45RB) dari sel T nodus limfe. Rangsangan TSH terhadap sel ini meningkatkan aktivitas fagositik dengan respon sitokin yang lebih baik yang mengikuti aktivasi fagositosis. $^{25}$

\section{c. Dampak klinis TSH pada tulang}

Thyroid-stimulating hormone receptor juga terlibat dalam fungsi jaringan ektratiroid yang lain, termasuk tulang. Thyroid-stimulating hormone receptor diekspresikan oleh osteoblas dan osteoklas, namun perannya masih belum jelas. Beberapa penelitian mengemukakan osteoporosis yang berhubungan dengan keadaan hipertiroid tidak hanya disebabkan karena aksi hormon tiroid yang berlebihan, namun kehilangan sinyal TSH karena kadar TSH yang tertekan juga berkontribusi terhadap terjadinya osteoporosis. $^{27}$

Thyroid-stimulating hormone receptor juga terlibat dalam fungsi jaringan ektratiroid yang lain, termasuk tulang. Thyroid-stimulating hormone receptor diekspresikan oleh osteoblas dan osteoklas, namun perannya masih belum jelas. Beberapa penelitian mengemukakan osteoporosis yang berhubungan dengan keadaan hipertiroid tidak hanya disebabkan karena aksi hormon tiroid yang berlebihan, namun kehilangan sinyal TSH karena kadar TSH yang tertekan juga berkontribusi terhadap terjadinya osteoporosis. $^{27}$

Mekanisme disfungsi tiroid yang menyebabkan efek terhadap pertumbuhan tulang masih belum dipahami sepenuhnya. Dulu diperkirakan hormon tiroid merupakan mediator utama dari remodeling tulang. Williams (2011) mengatakan bahwa kadar TSH yang rendah atau tinggi memiliki peran penting dalam metabolisme dan homeostasis tulang. $\mathrm{Hal}$ ini didukung oleh data dari tikus yang tidak memiliki reseptor tiroid dengan kelainan morfogenesis dan growth plate tulang, ternyata tidak ditemukan aksi osteoklas dan osteoblas yang patologis dan didapatkan densitas tulang yang normal. ${ }^{6,9,27}$ 
Mekanisme disfungsi tiroid yang menyebabkan efek terhadap pertumbuhan tulang masih belum dipahami sepenuhnya. Dulu diperkirakan hormon tiroid merupakan mediator utama dari remodeling tulang. Williams (2011) mengatakan bahwa kadar TSH yang rendah atau tinggi memiliki peran penting dalam metabolisme dan homeostasis tulang. Hal ini didukung oleh data dari tikus yang tidak memiliki reseptor tiroid dengan kelainan morfogenesis dan growth plate tulang, ternyata tidak ditemukan aksi osteoklas dan osteoblas yang patologis dan didapatkan densitas tulang yang normal. ${ }^{6,9,27}$

Ma et al (2011) menyatakan bahwa ikatan TSHR dengan antibodi melindung tulang dari hormon tiroid yang berlebihan saat tirotoksikosis. Peneliti ini juga menggunakan tirostimulin rekombinan, namun juga tidak memberikan efek. Penelitian ini mempertanyakan keterlibatan TSHR pada remodeling tulang dan, jika terlibat, jalur signaling tanpa respon cAMP. $^{28}$

Peran TSH dan TSHR pada metabolisme tulang diperkuat oleh penelitian pada manusia dengan TSHR Asp727Glu polymorphism. Penelitian in vitro menunjukkan peningkatan respon cAMP terhadap $\mathrm{TSH}$, namun secara in vivo ekspresi polimorfisme ini berhubungan dengan penurunan kadar TSH. Subyek dengan TSHR Asp727Glu memiliki peningkatan BMD dan mineral tulang femur. Hal ini menunjukkan polimorfisme berhubungan dengan gain of function TSHR yang relatif, yang selanjutnya akan mempengaruhi bone turnover. ${ }^{6,27}$

Peran TSH dan TSHR pada metabolisme tulang diperkuat oleh penelitian pada manusia dengan TSHR Asp727Glu polymorphism. Penelitian in vitro menunjukkan peningkatan respon cAMP terhadap $\mathrm{TSH}$, namun secara in vivo ekspresi polimorfisme ini berhubungan dengan penurunan kadar TSH. Subyek dengan TSHR Asp727Glu memiliki peningkatan BMD dan mineral tulang femur. Hal ini menunjukkan polimorfisme berhubungan dengan gain of function TSHR yang relatif, yang selanjutnya akan mempengaruhi bone turnover. ${ }^{6,27}$

\section{d. Dampak klinis TSH pada kelenjar hipofisis anterior}

Pada kelenjar hipofisis anterior, ekspresi TSHR ditemukan pada sel folikulo-stelata dan dikenal memediasi inhibisi umpan balik sekresi TSH dari tirotropik secara parakrin. Aktivitas TSHR pada sel folikulo-stelata ini berkontribusi pada pengaturan aksis hipotalamus-hipofisis-tiroid. Tirostimulin, sebuah hormon glikoprotein yang disusun oleh subunit $\alpha$ dan $\beta$, merangsang produksi cAMP setelah berikatan dengan TSHR. Hal ini diekspresikan di hipofisis anterior dan hipotalamus, dan walaupun peran fisiologisnya belum jelas, tirostimulin kemungkinan memiliki peran dalam regulasi parakrin signaling $\mathrm{TSH}$ melalui aksi lokal yang dimediasi oleh TSHR pada hipofisis. $^{9}$

\section{e. Dampak klinis TSH pada hati}

Hati menjadi salah satu organ selain tiroid yang mengekspresikan TSHR. Beberapa penelitian menyatakan bahwa produksi C-reactive protein pada hati berkorelasi positif dengan kadar TSH pada pasien dengan hipotiroid subklinis. Penemuan tersebut menggambarkan kemungkinan hubungan antara TSH dengan hepatosit. Saat ini, kehadiran TSHR pada hepatosit menjadi isu yang diperdebatkan. Penelitian sebelumnya menyatakan bahwa jaringan hati mengekspresikan TSHR pada kucing dan tikus. Penelitian tersebut berhasil mendeteksi mRNA TSHR pada jaringan hati pasien dengan kelainan non-tiroid. Pada penelitian terakhir, ditemukan bahwa terdapat implikasi penting dari peran TSH melalui TSHR pada hati. ${ }^{29,30}$

Thyroid-stimulating hormone receptor pada hepatosit bersifat fungsional, yang dibuktikan dengan kemampuan TSH dalam menstimulasi produksi cAMP. Bukti ekspresi mRNA TSHR pada jaringan hati manusia pertama kali ditemukan dengan polymerase chain reaction (PCR), namun transkripsinya ditemukan terlalu rendah untuk menimbulkan fungsi biologis. Untuk menentukan protein TSHR pada hepatosit ini fungsional, dilakukan penilaian pada respon cAMP 
yang dirangsang oleh TSH. Hasilnya adalah produksi cAMP yang dirangsang oleh TSH bersifat dosedependent, yang membuktikan bahwa protein TSHR pada hepatosit bersifat fungsional. Kadar TSH yang digunakan pada penelitian ini lebih tinggi daripada kadar TSH pada orang normal atau pasien dengan hipotiroid, namun sama dengan kadar TSH pada preadiposit 3T3-L1 dan fibroblas. Kadar TSH yang lebih rendah dibutuhkan oleh tubuh karena adanya kemungkinan aksi sinergis dari faktor pertumbuhan atau sitokin seperti IGF-1 yang memperkuat signaling TSH. Selain itu, juga ditemukan bahwa TSAb juga bisa merangsang produksi cAMP pada hepatosit. ${ }^{29,30}$

Penemuan terbaru mengenai TSHR pada hati membuktikan bahwa ekspresi fungsional dari TSHR di hepatosit memiliki implikasi fisiopatologis yang penting. Akumulasi cAMP yang dirangsang oleh TSH di hepatosit menunjukkan bahwa adanya hubungan fisiologis antara fungsi hati dan sistem endokrin melalui TSH dan TSHR. Adanya kehadiran TSHR di hepatosit juga menimbulkan gagasan bahwa hubungan TSHR dengan antigen tertentu bisa terjadi di hati. Hubungan ini bisa menjelaskan kejadian patologis antara TSAb dan kelainan yang ditimbulkannya pada organ tubuh. Zhang et al (2008) menyatakan bahwa pada penyakit Graves, TSAb dapat merangsang pembentukan cAMP di hati. Walaupun terdapat banyak hubungan klinis dan laboratorium antara kelainan tiroid dan hati, penelitian sampai saat ini berfokus pada hubungan antara hormon tiroid dan hati. ${ }^{29,30}$

Song et al (2015) menemukan bahwa TSH melalui jalur CAMP/PKA yang diaktivasinya menurunkan ekspresi dari hepatocyte nuclear factor (HNF)-4a. Hepatocyte nuclear factor-4a merupakan reseptor nuklear yang memainkan peran penting dalam diferensiasi hepatosit dan mempertahankan homeostasis hati, usus, dan sel $\beta$ pankreas. ${ }^{30}$

Song et al (2015) menemukan bahwa TSH melalui jalur cAMP/PKA yang diaktivasinya menurunkan ekspresi dari hepatocyte nuclear factor (HNF)-4a. Hepatocyte nuclear factor-4a merupakan reseptor nuklear yang memainkan peran penting dalam diferensiasi hepatosit dan mempertahankan homeostasis hati, usus, dan sel $\beta$ pankreas. ${ }^{30}$
SIMPULAN

Thyroid-stimulating hormone

memberikan dampak klinis jika berikatan dengan thyroid-stimulating hormone receptor (TSHR). Dampak klinis TSH pada kelenjar tiroid adalah mengatur pertumbuhan kelenjar tiroid, mempertahankan arsitektur kelenjar tiroid, dan mengatur sintesis hormon tiroid. Dampak klinis TSH pada jaringan adiposa adalah meningkatkan adipogenesis dan merangsang lipolisis. Dampak klinis TSH pada sistem imun adalah meningkatkan produksi sitokin, seperti interleukin-6. Dampak klinis TSH pada tulang adalah mempertahankan bone mineral density. Dampak klinis TSH pada kelenjar hipofisis anterior adalah memediasi inhibisi umpan balik TSH secara parakrin. Dampak klinis TSH pada hati adalah mengatur metabolisme glukosa dan lemak melalui hepatocyte nuclear factor4a. Dampak klinis TSH pada hati adalah mengatur metabolisme glukosa dan lemak melalui hepatocyte nuclear factor- $4 \alpha$.

\section{DAFTAR PUSTAKA}

1. Goel R, Raju R, Maharudraiah J, Kumar G, Ghosh $\mathrm{K}$, Kumar A, et al. A signaling network of thyroidstimulating hormone. J Proteonomic Bioinfrom. 2011;4.

2. Brent G. Mechanism of thyroid hormone action. Journal of Clinical Investigation.2012;122(9):303543.

3. Magner J. Historical note: Many steps led to the discovery of thyroid-stimulating hormone. Eur Thyroid J. 2014;3:95-100.

4. Sarapura VD, Gordon DF, Samuels MH. Thyroidstimulating hormone in The Pituitary. Edisi ke-3. London: Elsevier; 2011.

5. Pagana KD, Pagana TJ. Mosby's manual of diagnostic and laboratory tests. Missouri: Elsevier. 2002.

6. Lloyd A, Bursell J, Gregory J, Rees D, Ludgate M. TSH receptor activation and body composition. Journal of Endocrinology. 2010;204:13-20.

7. Hall JE. Introduction to endocrinology in Guyton and Hall Textbook of Medical Physiology. Philadelphia: Elsevier. 2011. 
8. Sorisky A, Gagnon A. Freedom of expression beyond the thyroid:the thyroid-stimulating hormone receptor in the adipocyte. OA Biochemistry. 2014;22(2):1-6.

9. Williams G. Extrathyroidal expression of TSH receptor. Annals d'Endocrinologie. 2011;72:68-73

10. Szkudlinski M, Fremont C, Ronin C, Weintraub B. Thyroid-stimulating hormone and thyroidstimulating hormone receptor structure-function relationship. Physiol Rev. 2002;82:473-502.

11. Kaiser U, Ho KK. Pituitary physiology and diagnostic evaluation in Williams Textbook of Endocrinology. Philadelphia: Elsevier. 2016

12. Lazar M, Birnbaum B. Principles of hormone action in Williams Textbook of Endocrinology. Philadelphia: Elsevier. 2016

13. Haugen BR. Drugs that suppress TSH or cause central hypothyroidism. Best Pract Res Clin Endocrinol Metab. 2009;23(6):793-800.

14. Peeters R, van der Deure W, Visser T. Genetic variation in thyroid hormone pathway genes; polymorphism in the TSH receptor and the iodothyronine deiodinases. European Journal of Endocrinology. 2006;155:655-62.

15. Alkemade A, Friesema E, Kuiper G, Wiersinga W, Swaab D, Visser TJ. Novel neuroanatomical pathways for thyroid hormone action in the human anterior pituitary. European Journal of Endocrinology. 2006;154:491-500.

16. Tsui S, Naik V, Hoa N, Hwang C, Afifiyan N, Hikim A. Evidence for an association between thyroidstimulating hormone and insulin-like growth factor 1 receptors: A tale of two antigens implicated in Graves' disease. Journal of Immunology. 2008;181:4397-405.

17. Nanniperi M, Cecchetti F, Anselmino M, Camastra $S$, Niccolini $P$, Lamacchia $M$. Expression of thyrotropin and thyroid hormone receptors in adipose tissue of patients with morbid obesity and/or type 2 diabetes: effects of weight loss. International of Journal of Obesity. 2009;33:1001-6

18. Jiang $D$, Ma S, Jing F, Xu C, Yan F, Wang A, Zhao J. Thyroid-stimulating hormone inhibits adipose triglyceride lipase in 3T3-L1 adipocytes through the PKA pathway. Plos One. 2015;10(1):1-9.
19. Ma S, Jing F, Xu C, Zhou L, Song Y, Yu C, Jiang $D$, et al. Thyrotropin and obesity: increased adipose triglyceride content through glycerol-3phosphate acyltransferase 3 . Scientific Reports. 2015;5:1-10.

20. Mukherjee B, Hossain CM, Mondal L, Paul P, Ghosh MK. Obesity and insulin resistance: an abridged molecular correlation. Lipid Insights. 2013;6:1-11.

21. Walter KN, Corwin EJ, Ulbrecht J, Demers LM, Bennett JM, Whetzel CA, Klein LC. Elevated thyroid stimulating hormone is associated with elevated cortisol in healthy young men and women. Thyroid Research.2012;5(13):1-6.

22. Ruhla S, Weickert MO, Arafat AM, Osterhoff $M$, Isken F, Spranger J, Schofl C. A high normal TSH is associated with the metabolic syndrome. Clinical Endocrinology. 2010;72:696-701.

23. Chen S, Shauer A, Zwas DR, Lotan C, Keren A, Gotsman I. The effect of thyroid function on clinical outcome in patients with heart failure. European Journal of Heart Failure. 2014;16:217-26.

24. Debeij J, Cannegieter SC, Zaane B, Smit JW, Corssmit EP, Rosendaal FR, Romijn JA, et al. The effect of changes in thyroxine and thyroidstimulating hormone levels on the coagulation system. Journal of Thrombosis and Haemostasis; 8:2823-5.

25. Raychaudhuri M, Fernando R, Smith T. Thyrotropin regulates IL-6 expression in CD34 fibrocytes: Clear delineation of its CAMP-independent actions. Plos One. 2013;8(9):1-12.

26. Smith TJ. TSH-receptor-expressing fibrocytes and thyroid-associated ophtalmopathy. Nature Reviews Endocrinology. 2015.

27. Ohn J, Han S, Park D, Park K, Park Y. Expression of thyroid stimulating hormone receptor mRNA in mouse $\mathrm{C} 2 \mathrm{C} 12$ skeletal muscle cells. Endocrinol Metab.2013;28:119-24.

28. Ma R, Morshed S, Latif R, Zaidi M, Davies TF. The influence of thyroid-stimulating hormone and thyroid-stimulating hormone receptor antibodies on osteoclastogenesis. Thyroid. 2011; 21(8): $897-$ 905. 
29. Zhang W, Tian L, Han Y, Ma H, Wang L, Guo L, Gao L, et al. Presence of thyrotropin receptor in hepatocytes: not a case of illegitimate transcription. J Cell Mol Med. 2009;13(11):4636-42.
30. Song Y, Zheng D, Zhao M, Qin J, Wang T, Xing W, Gao $\mathrm{L}$, et al. Thyroid-stimulating hormone increases HNF-4 $\alpha$ phosphorylation via cAMP/PKA pathway in the liver. Nature Scientific Reports.2015;5:1-8. 